\title{
The Intention-to-Repurchase Paradox: A Case of the Health and Fitness Industry
}

\author{
Alain Ferrand \\ Université Poitiers \\ Leigh Robinson \\ Loughborough University \\ Pierre Valette-Florence \\ Universite Pierre Mendes
}

The article proposes a conceptual model to examine the relationships between service attributes, brand associations, customer satisfaction, commitment, price of membership, and intention to repurchase in a fitness club. The results show that the services offered by the club, its security, and the promoted image of the club impact positively on satisfaction. The customer relations at the club, customer commitment, and their frequency of weekly attendance have a positive direct effect on intention to repurchase. Perceived price has a negative direct influence. Finally, the research showed that overall satisfaction has a slight positive impact on frequency of attendance. These findings create a paradox for managers of health and fitness organizations who will have to balance the need to increase frequency of attendance to positively impact on intention to repurchase with the need to deliver the service attributes that affect satisfaction and intention to repurchase at high quality level.

The factors that lead customers to continue to use a particular organization have been subject to extensive research which has focused on service quality (Olorunniwo, Hsu, \& Udo, 2006; Parasuraman, Zeithaml, \& Berry, 1985, 1994a, 1994b) satisfaction (Jones \& Suh, 2000; Murray \& Howat, 2002; Söderlund, 2006), and image (Lassar, Mittal, \& Sharma, 1995; Zins, 2001). Although the factors investigated may be different, there is general agreement that the retention of customers is fundamental to the success of an organization (Oliver, 1999; Söderlund, 2006; Zeithaml, Berry, \& Parasuraman, 1996). The notion of customer retention is encapsulated by the concept of customer loyalty (Ganesh, Arnold, \& Reynolds, 2000; Zins, 2001) and it is evident that loyal customers are considered key to organizational profitability and success. Selin, Howard, Udd, and Cable (1987)

Ferrand is with Université Poitiers, Poitiers, France. Robinson is with the Institute of Sport and Leisure Policy, Loughborough University, Loughborough, UK LE11 3TU. Valette-Florence is with CERAG, Universite Pierre Mendes, Grenoble, France. 
found that consumers of municipal recreation programs who demonstrated the greatest levels of loyalty to the service tended to repurchase more often and spend more money. In addition, research carried out with theater customers showed that greater levels of loyalty led to greater repurchase behavior (Divett, Crittenden, \& Henderson, 2003). From this it is apparent that it is of benefit to organizations to create loyal customers.

Customer loyalty is of particular importance to the health and fitness industry given its operating context. Research carried out by the International Health, Racquet and Sportsclub Association (IHRSA; 2006) showed that health and fitness club expansion and club revenue growth has either slowed markedly, or declined over the period of 2002-2005. This is particularly evident in the health and fitness club industry in France which is the focus of this research. The customer base for the health and fitness market in France, small to begin with, has been shown to be declining. According to a study carried out in 2003, 10\% of French adults were members of a health and fitness club, which was a decline of $9 \%$ in 2002 (Ipsos, 2005). The IHRSA (2006) study showed further decline with only $6 \%$ of the French population belonging to health and fitness clubs in 2005. The consequence of this is that the number of health and fitness clubs in France fell $30 \%$ during the period of 2000-2005. Indeed the Club Med Gym, the focus of this research, saw its number of clubs decline from 144 in 2001-23 in 2004 (IHRSA, 2006). Therefore the creation of loyal customers appears paramount for survival in the health and fitness industry.

Three conceptual perspectives have emerged from customer loyalty research (Dimitriades, 2006; Söderlund, 2006). The first is the behavioral perspective which is primarily concerned with repeat purchase behavior. This conceptualization of loyalty based on past purchase behavior and probability of purchase has, however, been criticized for its lack of a cognitive element to explain underlying motives (Hellier, Geursen, Carr, \& Rickard, 2003; Zins, 2001). The second, the attitudinal perspective is concerned with the degree to which a customer is favorably disposed toward a service, reflected by their recommendation of the service provider to other consumers (Dimitriades, 2006). In research carried out in a recreational sport context, Park and Kim (2000) considered attitudinal loyalty to be a process of psychological attachment to a recreation program and found that some aspects of this conceptualization of loyalty led to increased intention to repurchase. However, this perspective has also been criticized in that it does not actually explain purchasing behavior (Söderlund, 2006; Zins, 2001). The third conceptualization, the composite perspective is a two-dimensional conceptualization of loyalty (Jones \& Taylor, 2007) which defines loyalty using both behavior and attitude. Park and Kim's (2000) research found that attitudinal loyalty had an impact on behavioral loyalty, leading them to support the notion of a two-dimensional loyalty construct.

It is apparent from the above discussion that, as noted by Jones and Taylor (2007) and Söderlund (2006), there is no agreement on the definition of loyalty as each of the conceptualizations presented above has been found to explain customer loyalty in different research contexts. This lack of a common consensus also extends to the measurement of loyalty where Jones and Taylor (2007) and Zins (2001) have argued for a composite measure of loyalty, whereas Söderlund (2006) and Reichheld (2003) have argued for a single measure of loyalty, such as intention to repurchase, or word of mouth. 
Söderlund (2006) has argued particularly strongly for researchers to use a single measure of loyalty in empirical work. Drawing on the organizational theory and interpersonal loyalty literature, he sets out his argument on the basis that composite measures of loyalty that combine, for example, repurchasing intention with word of mouth intention are actually dealing with different behaviors. Distinguishing the concepts as "talk behaviors" and "doing behaviors," he highlights how they have different objects and different consequences for the organization, stating that repatronage has a direct economic consequence for an organization whereas word of mouth may or may not lead to patronage. His research carried out with restaurant diners and customers of an electronic organization supports this argument and leads him to conclude that a composite measure of loyalty is likely to hide significant aspects of loyalty, including other variables that may impact on loyal behavior.

As a consequence of the impact that customer retention has on organizational profitability (McIlroy \& Barnett, 2000; Oliver, 1999), this research is concerned with behavioral loyalty, and specifically with repurchasing behavior. A number of researchers have identified the increased cost of obtaining new customers in comparison with the costs of retaining existing customers (Fornell \& Wernerfelt, 1987; Lovelock \& Wright, 1999; Zeithaml et al., 1996). In addition, the longer a customer stays with the organization the more profitable customers become as they use more of an organization's services over time (McIlroy \& Barnett, 2000; Söderlund, 2006). Thus, knowledge of future continued use is essential in an industry showing a slow down or decline in growth to help with financial forecasting and future planning and therefore this form of customer loyalty is of importance to this research. This requires an understanding of the factors that lead to behavioral loyalty and which impact on intention to repurchase. As such, the research set out in this paper aims to establish the relationships between a number of variables and customers' intention to repurchase (renew) their membership.

\section{The Factors Affecting Intention to Repurchase}

A review of the existing research in this area identifies a number of variables as having an impact on intention to repurchase. For example, Murray and Howat (2002) found a positive relationship between service quality, customer satisfaction and intention to repurchase among customers of an Australian sport and leisure center. Jiang and Rosenbloom (2005) established that satisfaction and price perception influenced intention to return among e-retailing customers. Divett et al. (2003) identified how important service attributes increased repurchasing behavior among theater goers, a finding replicated by Hill and Green (2000) in their research carried out with spectators of rugby league matches. Finally, Grace and O'Cass (2005) found that brand had a significant impact on reuse intentions. The following discussion considers these variables and their relationship to intention to repurchase in more detail.

\section{Customer Satisfaction}

There is an extensive body of literature across a number of research settings that supports the positive influence that satisfaction has on intention to repurchase (Bernhart, Donthu, \& Kennet, 2000; Cronin \& Taylor, 1994; Söderlund, 2006). 
Bitner, Booms, and Tétreault (1990) and Jones and Suh (2000) found that overall satisfaction with an organization had a direct impact on how likely customers were to reuse the service. In a banking environment, Ganesh et al. (2000) found a direct link between dissatisfaction and switching behavior and that satisfaction was a strong antecedent to intention to repurchase. Howat, Murray, and Crilley (1999) found that satisfaction of customers of sport centers was positively related to their willingness to recommend a service, repurchase from the provider and increase frequency of visits.

Although there is also a small body of research that suggests that the relationship between the two variables is not as direct as the discussion above may suggest (Hellier et al., 2003; Oliver, 1999; Zins, 2001), the research presented above provides strong evidence of the positive impact that customer satisfaction has on intention to repurchase. This leads to the following hypothesis:

$\mathrm{H} 1$ : Intention to repurchase is positively influenced by overall satisfaction.

\section{Service Attributes}

Service attributes are the activities, physical properties, people and intangible elements, offered by an organization, that are perceived by customers to make up a service. Pioneering work done by Parasuraman, Zeithaml, and Berry (1988) identified several attributes that customers consider important and thus, expect from a service, which they then categorized into the dimensions of responsiveness, assurance, tangibles, empathy and reliability. In the sport field, Crompton, McKay, and Fesenmaier (1991) found that the attributes that make up four of these dimensions, responsiveness, assurance, tangibles, and reliability, were applicable to recreation service delivery. Subsequent research with customers of 15 public sport and leisure centers established a four dimensional model of attributes considered important, made up of core services, staff quality, general facility, and secondary services (Howat, Crilley, Absher, \& Milne, 1996).

In similar research carried out in the UK, Lentell (2000) found that the importance of service attributes created three dimensions, which were physical evidence, staff, and secondary services. Papadimitriou and Karteroliotis (2000) established an alternative four dimensional model of important service attributes consisting of instructor quality, facility attraction and operation, program availability, and other services.

However, it is difficult to determine from research in this area what the most important service attributes may be. For example, research carried out in Greece by Costa, Tsitskari, Tzetzis, and Goudas (2005) and Theodorakis and Kambitsis (1998) found that many of the attributes identified by Parasuraman et al. (1988) were important to the service, but also added attributes that were specific to the context of their research. Of direct relevance, in research carried out with customers of a health club in Greece, Alexandris, Zahariadis, Tsorbatzoudis, and Grouios (2004) found that as well as the attributes identified initially by Parasuraman et al. (1988), a nice atmosphere and the acceptable behavior of other customers were also considered to be of key importance to the service. From this, it is apparent that, although there are a number of common important attributes to be found in the research such as cleanliness, good staff, consistent and reliable services, and security, there is no clear agreement on what is important to a specific service situation. Therefore it will be 
necessary to establish which attributes are important to the customers included in this research before establishing the impact of important attributes on intention to repurchase.

The relationship between the importance of service attributes and intention to repurchase appears to be primarily indirect in that the majority of the literature shows that service attributes have a positive impact on satisfaction, which, as outlined above, has been shown to impact on intention to repurchase. The relationship between service attributes and satisfaction has been well researched in the sport context and it is apparent that important service attributes impact positively on customer satisfaction (Alexandris et al., 2004; Costa et al., 2005). Satisfaction then acts as a mediating variable on intention to repurchase, leading to the following hypothesis:

$\mathrm{H} 2$ : Overall satisfaction is positively influenced by the importance of service attributes.

There is, however, not consistent agreement about which service attributes lead to satisfaction. In studies carried out in the hotel industry, Erto and Vanacore (2002) and Olorunniwo et al. (2006) found that the importance of staff and cleanliness were the only factors that had a direct impact on satisfaction. Ganesh et al. (2000) found that attributes relating to staff and costs were key for customers of banks and the work of Busacca and Padula (2005) carried out with mobile phone users, found that the importance of staff and tangibles had an impact on satisfaction.

Within the sport context, Lentell (2000) established that of the three dimensions of public sport and leisure services that led to satisfaction, the physical evidence of the facility had the greatest impact on satisfaction. Papadimitriou and Karteroliotis (2000) carried out similar research in Greece and established that the quality of instructors was paramount, followed by the facility attraction and operation, the availability of the program, and the way it was delivered. In their research with children attending athletic camps in Greece, Costa et al. (2005) found that relationships, tangible factors, security, activities, and contentment affected satisfaction with the experience, in this order of impact on satisfaction.

Finally, in their study of health and fitness club members, Alexandris et al. (2004) found that the physical environment had the strongest influence on satisfaction, followed by interaction with staff. Interestingly, a positive outcome derived from belonging to the health club also had a strong positive impact on satisfaction. It seems reasonable to argue therefore that not all important service attributes have the same impact on customer satisfaction.

In addition to the extensive literature setting out the impact of important service attributes on customer satisfaction, there is small body of research that has established that service attributes can impact directly on intention to repurchase. Jones and Taylor (2007) established that staff who exhibited prorelationship behaviors, such as the attributes of empathy, responsiveness, and interest created loyalty and intention to repurchase among 300 service customers. In research carried out with airline passengers, Nadiri, Hussain, Ekiz, and Erdoğan (2008) identified that the tangible attributes of the airline and the terminal, as well as the behavior and the empathy showed by staff_-all considered important—had a direct positive impact on intention to repurchase. In their research carried out with customers of Greek fitness clubs Alexandris, Dimitriadis, and Kasiara (2001) established that the tangible attributes of the clubs included in the research, considered important by customers, impacted positively on intention to repurchase. This research also established that 
the attributes of reliability and assurance had a direct impact in some club settings. This leads the following hypothesis to be proposed:

H3: Intention to repurchase is positively influenced by the importance of service attributes.

\section{Brand}

The concept of brand has attracted a great deal of interest from researchers who have focused on the associations that make up a brand (Gladden \& Funk, 2002; Ross, James, \& Vargas, 2006), the image these attributes create (Beccarini \& Ferrand, 2006; Ferrand \& Vecchiatini, 2002), and the value that this adds to the organization, known as brand equity (Gladden, Milne, \& Sutton, 1998; Ross, 2006).

Keller (1993) has argued that brand associations are informational nodes that contain the meaning of the brand for consumers and have been identified as being critical in building strong brands (Chen, 2001; Ross, 2006). Categorized as attributes, benefits, and attitudes (Keller, 1993), or product association and organizational association (Chen, 2001), brand associations are perceived to be the basis for purchasing decisions and for brand loyalty (Aaker 1991, 1996; Belén del Río, Vázquez, \& Iglesias, 2001). This is because, as argued by Aaker (1991, 1996) associations build a psychological construct made up of the rational and affective dimensions held by a group or person about a service. This construct is the brand image which is related to the "network of strong, favorable, and unique brand associations in consumer memory" (Keller 1993, p. 8) and brand image is important as it directs behavior such as intention to repurchase (Fredericks \& Salter, 1995).

There is limited evidence to support a direct relationship between aspects of brand and intention to repurchase (Kandampully \& Suhartanto, 2000; Nadiri et al., 2008; Zins, 2001). The more common relationship is that aspects of brand make an impact on satisfaction, which in turn, as discussed above, impacts on intention to repurchase. For example, Pappu and Quester (2006) established that agreed brand associations of retail organizations varied significantly as a function of satisfaction, while Esch, Langner, Schmitt, and Geus (2006) established a positive relationship between brand image and satisfaction. Bolton and Drew (1991) and Johnson and Fornell (1991) stressed the fact that when services are difficult to evaluate corporate image is a major factor that influences customer satisfaction with the service. Andreassen and Lindestad (1998) also noted that corporate image may create a halo effect on customers' satisfaction judgments.

In a sport context, the influence of brand image on satisfaction has been investigated in the ski industry by Ferrand and Vecchiatini (2002) who stressed that the corporate image of a ski resort has a direct positive effect on skiers' overall satisfaction. This direct effect was confirmed in a study by Beccarini and Ferrand (2006) of soccer club season ticket holders.

However, although brand image appears important when investigating repurchasing relationships, for research purposes brand associations are of greater importance. Brand image can be decomposed into the brand associations which are agreed by customers to create the organization's image (Zins, 2001) which can then be incorporated into research questionnaires. More importantly as discussed by Aaker (1991) and Ross (2006, p. 30) brand associations "represent the basis for 
purchase decisions and for brand loyalty." From this, the following relationship between brand associations and satisfaction can be hypothesized:

$\mathrm{H} 4$ : Overall satisfaction is positively influenced by agreed brand associations.

\section{Previous Purchase Behavior}

A relationship between previous purchase behavior and future intention to repurchase is intuitively obvious. Oliver (1999) argued that a customer with a history of purchasing from an organization becomes 'committed' and does not look to switch providers; indeed they may be oblivious to competition. Similarly, in their research carried out with restaurant diners, McIlroy and Barnett (2000) argued that a long term relationship needed to be built up with customers to encourage future intentions to repurchase, noting that customers with a long term relationship with an organization remain loyal to a brand and do not respond to competitor offers. Thus, the fifth hypothesis of this research is:

$\mathrm{H} 5$ : Intention to repurchase is positively influenced by previous purchasing behavior.

\section{Perceptions of Price}

There is limited evidence in the literature relating to perceptions of price and intention to repurchase. However, the literature that does exist suggests a relationship between perceptions of price and intention to repurchase. For example, in research carried out with e-retailers, Jiang and Rosenbloom (2005) found a direct positive effect of price perceptions on reuse in that the cheaper the price, the more likely customers were to reuse, while service setting research carried out by Keaveney (1995) found that half of the customers surveyed had switched service provider because of poor perceptions of price. From this, it appears that negative perceptions of price are likely to have a negative effect on intention to repurchase and thus, the following hypothesis is proposed:

H6. Intention to repurchase is negatively influenced by perceptions of the price of membership.

\section{The Research Model}

The theoretical basis of the research model (Figure 1) has as its underpinning assumption that there is a positive relationship between satisfaction and intention to repurchase, an assumption which is supported by the work of authors such as Bernhart et al. (2000), Jones and Suh (2000), Murray and Howat (2002), Olorunniwo et al. (2006), and Söderlund (2006). In addition, the review of literature identified a number of relationships between the variables under study. As a consequence, the research will test the hypotheses outlined in the previous discussion.

In addition, anecdotal evidence from managers and the health and fitness industry press (Ferrand \& Nardi, 1995) suggested that frequency of visits tended to decline in customers not intending to renew their membership. Although the reasons for this are not clear, it was suggested by managers that this may be due to decreasing satisfaction with the service. Thus, the research model also included the following hypotheses: 


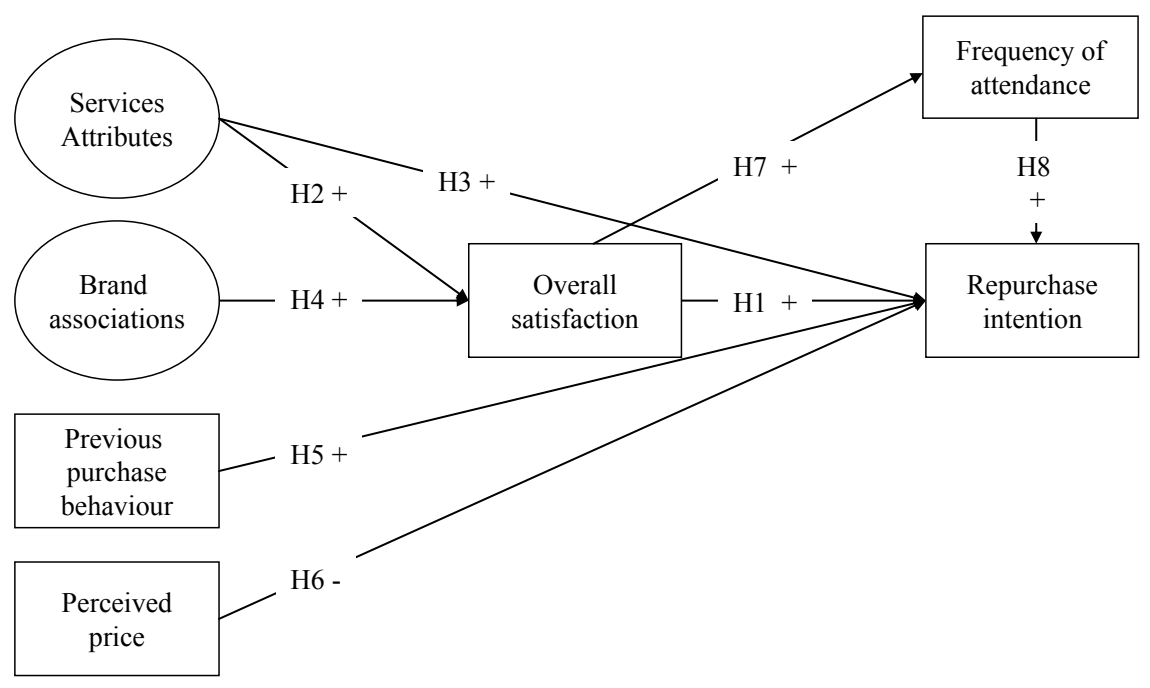

Figure 1 - Conceptual model.

H7: Overall satisfaction positively influences frequency of attendance.

H8: Intention to repurchase is influenced by frequency of attendance.

Each of the model components is defined as follows:

Service attributes: the importance of the components provided by the organization that allow the customer to experience the service;

Brand associations: the functional and emotional associations which are assigned to a brand by the customer;

Overall satisfaction: the degree of overall contentment felt by the customer which has come from the ability of the service to meet desires, needs, and expectations;

Price: customer's perception of the price of membership fees;

Previous purchase behavior: the degree to which the customer has maintained a relationship with the organization;

Frequency of attendance: the average number of visits a customer makes to the club each week;

Intention to repurchase: the customer's judgment about resubscribing again to the organization, taking into account their current situation and likely circumstances.

\section{Method}

To investigate the factors affecting intention to repurchase, empirical research was carried out with the customers of Club Med Gym located in Grenoble, France, which is part of the Club Med Gym health and fitness chain. Club Med Gym is the largest health and fitness chain in France with 17 clubs and charges a premium price for 
Table 1 Respondent Characteristics

\begin{tabular}{|c|c|c|c|}
\hline & Interviews & $\begin{array}{c}\text { Pilot } \\
\text { Questionnaire }\end{array}$ & $\begin{array}{c}\text { Final } \\
\text { Questionnaire }\end{array}$ \\
\hline Gender & Percentage & Percentage & Percentage \\
\hline Female & 47.50 & 55.83 & 55.79 \\
\hline Male & 52.50 & 44.17 & 44.21 \\
\hline \multicolumn{4}{|l|}{ Period of use } \\
\hline 7.30 a.m. to noon & 17.50 & 15.00 & 16.74 \\
\hline Noon to 2 p.m. & 20.00 & 20.83 & 18.03 \\
\hline 2 p.m. to 6 p.m. & 20.00 & 23.33 & 20.17 \\
\hline 6 p.m. to 8.30 p.m. & 26.00 & 22.50 & 25.75 \\
\hline 8.30 p.m. to 10.30 p.m. & 17.50 & 18.33 & 19.31 \\
\hline \multicolumn{4}{|l|}{ Age* $^{*}$} \\
\hline Under 30 & 22.50 & 21.67 & 19.74 \\
\hline $30-39$ & 30.00 & 30.83 & 30.90 \\
\hline $40-49$ & 27.50 & 25.83 & 28.33 \\
\hline \multirow[t]{2}{*}{50 and over 50} & 20.00 & 21.67 & 21.03 \\
\hline & $N=40$ & $N=120$ & $N=233$ \\
\hline
\end{tabular}

*Age is provided here for information purposes. It was not used to segment the sample as it was felt that customers may be uncomfortable telling reception staff their age to sample correctly.

club membership. It is owned by Club Méditerranée, a multinational corporation with its head office in France that specializes in 'all-inclusive' luxury holidays. Club Med Gym Grenoble has approximately 1,100 members and is a medium sized club in the chain. The research was carried out at the request of the Grenoble club management in response to an increasingly competitive environment that led to a perceived need to understand the factors that contribute to renewal of membership.

The research followed a three-phase procedure. In the first phase interviews were carried out with 40 customers of Club Med Gym, Grenoble, to develop a list of service attributes and brand associations that could be used in the research instrument. This was necessary as existing research does not provide a list of service attributes that are considered important for all service organizations, or a common set of agreed brand associations. The 40 customers interviewed were segmented on the basis of gender and time of visit, characteristics that were used for all phases of the research (Table 1). These characteristics were chosen to reflect the membership of the health and fitness club and because the importance of service attributes and perceptions of satisfaction are affected by these variables (Dimitriades, 2006; Kim \& Kim, 1998).

A semistructured format was used for the interviews and each interviewee was taken through the same central questions to ensure consistency (Patton, 2002). First, participants were asked to give details about their personal history with Club Med Gym, such as length of membership and preferred activities. The main section of the interview comprised specific questions relating to service attributes and associations related to the brand. For example, interviewees were asked the following: Can you specify the characteristics that are related to service quality for a fitness 
club? What comes into your mind when you think about the Club Med Gym brand? Which words and expressions do you associate with the Club Med Gym brand?

Two researchers who were experienced in qualitative methods and familiar with the concepts of service attributes and branding conducted all interviews. Interviewees were assured confidentiality and gave informed consent and this, alongside the quality of the relationship between interviewer and interviewees, enabled participants to talk freely about their experiences and views, and to be honest and open with their responses. The interviews were carried out without distractions, and each interview lasted approximately $20 \mathrm{~min}$. All interviews were audiotaped and transcribed verbatim by the interviewers. The interview transcripts were returned to the participants to check the content and the quality of the transcripts. The interviewees recommended no changes.

Inductive content analysis was used to analyze the interview transcripts. First, the interviews were transcribed and reported without any analysis. Following this, the two researchers read the transcripts thoroughly, and independently, for initial categorization. Finally, the researchers came together again to discuss the findings. When agreement was reached, the initial categories were combined into subthemes, which were subsequently combined into themes. Finally, the latter were regrouped into categories. To quantify the level of agreement between the two researchers, a Cohen's Kappa was computed which gave a value of 0.89 for brand attributes and 0.83 for services attributes, indicating a strong level of agreement between the two researchers. In a further step, peer debriefing sessions with health and fitness professionals and other researchers considered as "disinterested peers" (Lincoln \& Guba, 1985, p. 308) were conducted to examine methodological procedures, and to discuss and debate the researchers' interpretations of the overall findings. This process enhanced data credibility.

Through a process of content analysis 35 service attributes and 32 brand associations were identified. After deleting attributes and associations that were considered to have the same meaning, 25 service attributes and 21 brand associations were included in a pilot questionnaire. For example, cleanliness was considered to encapsulate clean floors and clean facilities, while holiday was felt to include holiday clubs and offers holidays.

The second phase, the pilot questionnaire, was completed by 120 randomly selected clients, once again segmented on the basis of gender and time of attendance as set out in Table 1. Reception staff asked every third and then every fifth person in accordance with the segmentation variables to complete the questionnaire, however, those involved in the first phase of the research were excluded from taking any further part in the research. The purpose of this questionnaire was to perform an exploratory factor analysis to determine the service attributes considered important and the brand associations that customers agreed were associated with the organization, and to refine the attributes to be used in the main study. For brand associations, respondents were asked to indicate their agreement, using a 5-point Likert-type scale ranging from 1 "completely disagree" to 5 "completely agree," with the statement in your opinion the Club Med brand means for each association. For service attributes, respondents were asked to indicate the importance of each attribute using a Likerttype scale from 5 'very important' to 1 'not at all important'.

Principal component analysis with promax rotation was used to analyze the results. Five service attributes and seven brand associations were dropped one by one 
from the analysis because their factor loadings were below the minimum loading criterion of 0.40 (Nunnally \& Bernstein, 1994, p. 460). The relationship among the remaining variables was assessed each time. The dropped attributes were cloakroom ventilation, large beverage range at the bar, easily adjusted equipment, easy access to the changing rooms, and party-oriented members. The dropped brand associations were flexibility, international, a large choice, powerful firm, physical training, safe, and for women. Thus, 20 service attributes and 14 brand associations remained for the final questionnaire. Internal reliabilities (Cronbach alpha) of each construct ranged from 0.76 to 0.84 for service attributes and 0.86 and 0.92 for brand associations, all exceeding the minimum criterion of 0.60 (Bagozzi \& Yi, 1988, p. 80).

Table 2 shows that the measurement construct for the importance of service attributes has five key dimensions. The most important is Services, which includes the programs available and the staff who delivered them. The second dimension is Customer relations and relates to the keeping of promises and management responsiveness. The third one is Nice to use and relates to facility organization, in particular the club's welcome and user-friendliness. The fourth is Security and is concerned with club equipment and safety. The last dimension, Comfort is related to club comfort and cleanliness. The factor analysis explains $66.31 \%$ of the variance which is satisfactory.

Table 3 presents the component's correlation matrix which shows that components 1 and 3 are the most correlated, sharing $3 \%$ of the information $\left(0.159^{2}\right)$.

Table 4 shows that the agreed associations with the Club Med Gym brand have two dimensions. The most important relates to Promoted image and includes the associations of professionalism and wellness, vitality and fitness, which are the brand attributes that are expressly promoted by the advertising and promotion activities of the Cub Med Gym. The second dimension, Additional benefits includes holidays, user friendliness and social relations. This analysis explains $69.33 \%$ of the variance. Promoted image explains $41.09 \%$ of the variance, while Additional benefits accounts for $28.24 \%$ of the variance. The correlation between the two components is .342 . Consequently they share $8 \%$ of the information $\left(0.342^{2}\right)$.

In the third phase of the research, the final questionnaires were distributed, as outlined above, over a one week period. Responses were collected from 264 out of 450 members, a 59\% response rate. The questionnaire included the attributes and associations established by the pilot, using the same question structure as in the pilot. Five other variables were also included to test the relationships in the research model.

First, previous purchase behavior was included in the research to test whether there is a positive relationship between previous behavioral loyalty and expressed future behavioral loyalty. This was considered important in an industry where health and fitness clubs compete for customers on the basis of heavy discounting to attract customers away from competitor organizations. Previous purchase behavior was measured by length of membership in years. Second, overall satisfaction with the Gym was included in the research to test H1, H2, H4 and H7. This was measured as a single item (How satisfied are you with the Gym overall?) and customers were requested to rate their overall satisfaction on a Likert-type scale from 5 "completely satisfied" to 1 "completely unsatisfied." The use of a single item measure of overall satisfaction is consistent with Bou-Llusar, Camison-Zornoza, and Escrig-Tena (2001) and Murray and Howat (2002). 


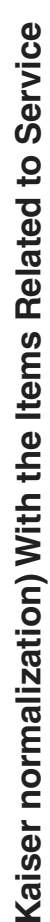

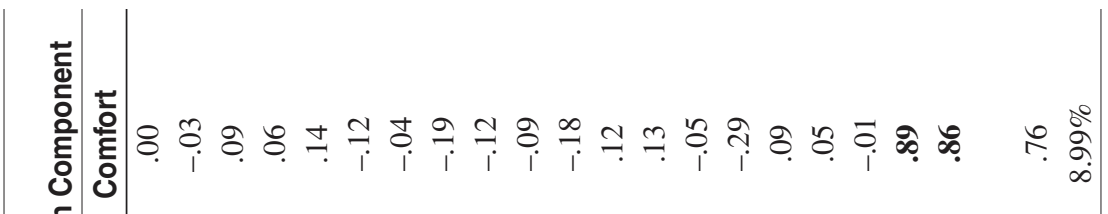

苞

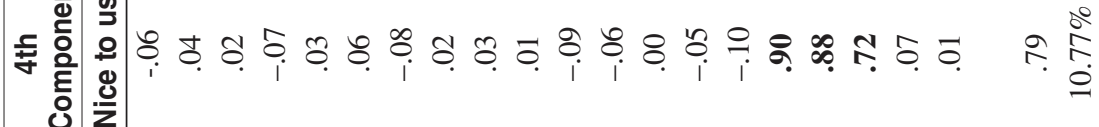

일

을

采

x

흔

임

$\frac{5}{5}$

尔

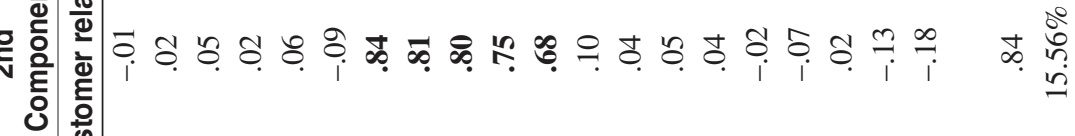

它

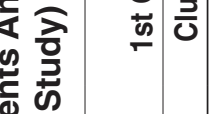

Ð

을믐

응 등

정

은 뚠

동

을 은

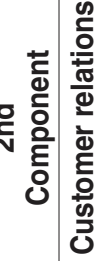

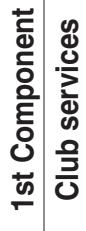

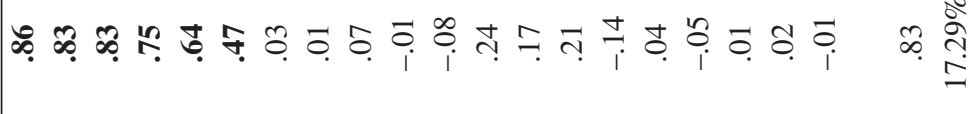

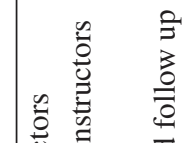

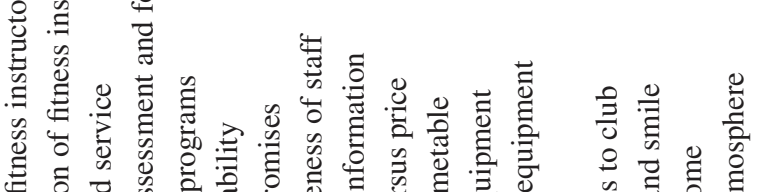

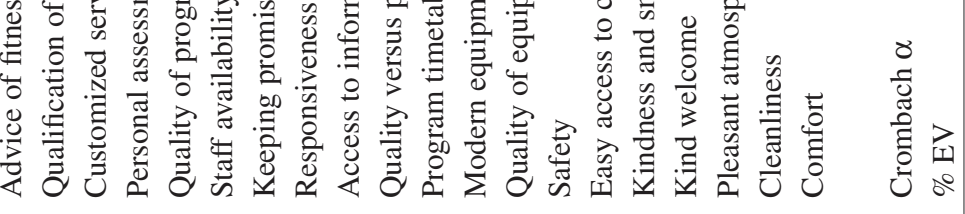


Table 3 Components Correlation Matrix (PCA Items Related to Service Attribute Satisfaction)

\begin{tabular}{lccccc}
\hline Components & $\begin{array}{c}\text { Club } \\
\text { Services }\end{array}$ & $\begin{array}{c}\text { Customer } \\
\text { Relations }\end{array}$ & Security & $\begin{array}{c}\text { Nice to } \\
\text { Use }\end{array}$ & Comfort \\
\hline Club services & 1.000 & .021 & .159 & .005 & .065 \\
Customer & & 1.000 & .069 & -.030 & -.136 \\
relations & & & & & \\
Security & & & 1.000 & -.055 & -.010 \\
Nice to use & & & & 1.000 & .055 \\
Comfort & & & & & 1.000 \\
\hline
\end{tabular}

Table 4 Principal Components Analysis (Promax with Kaiser Normalization) With the Associations Related to the Club's Brand (Pilot Study)

\begin{tabular}{lcc}
\hline & 1st Component & 2nd Component \\
\hline Promoted image & $\begin{array}{c}\text { Additional } \\
\text { benefits }\end{array}$ \\
\hline Recreation & $\mathbf{. 8 6}$ & .32 \\
Fitness & $\mathbf{. 3 3}$ & .37 \\
Professionalism & $\mathbf{. 8 0}$ & .00 \\
Dynamism and vitality & $\mathbf{. 7 7}$ & .34 \\
Service quality & $\mathbf{. 7 7}$ & .35 \\
Sport & $\mathbf{. 7 5}$ & .43 \\
Fun & $\mathbf{. 7 4}$ & .04 \\
Health & $\mathbf{. 7 3}$ & .34 \\
Sun & $\mathbf{. 7 3}$ & -.14 \\
Conviviality & .18 & $\mathbf{. 8 7}$ \\
Holiday & .41 & $\mathbf{. 8 5}$ \\
Place to meet people & .09 & $\mathbf{. 7 9}$ \\
Peacefulness & .14 & $\mathbf{. 7 6}$ \\
Crombach $\alpha$ & .33 & $\mathbf{. 7 0}$ \\
\% EV & & $\mathbf{8 6}$ \\
\hline
\end{tabular}

Customers' perception of the price of membership was assessed using a price perception scale from Srivastava (1999). This variable was included in the research to further contribute to an understanding of the impact of perceptions of price on intention to repurchase and is important given that, as set out above, much competition in the industry is on the basis of price. Customers were asked to rate their agreement with the statement Club Med Gym is expensive on a Likert-type scale from 5 'completely agree' to 1 'completely disagree'. 
Intention to repurchase was measured as a single item (Will you renew your membership with the club?). Customers were requested to rate their overall likelihood of renewing their membership on a Likert-type scale ( $5=$ definitely yes; $4=$ probably yes; 3 = I don't know; 2 = probably not; 1 = definitely not). Once again, the use of a single item measure is consistent with Murray and Howat (2002) and Söderlund (2006). Finally, although frequency of attendance has not been subject to previous research, it was apparent from discussions within the professional press and with club managers that there was a perception of a relationship between frequency of attendance and intention to repurchase. Therefore, this relationship was tested by the research (H8) and frequency of attendance was measured by asking members how many visits they made to the gym, on average, each week.

\section{Data Analysis and Results}

To test the hypotheses, a structural equation model using LISREL 8.53 (Joreskog \& Sorbom, 2003) was developed. The validity of the model was assessed in a two-step procedure. First, a measurement model of constructs was tested for key dimensions. Next, the hypothesized causal relationships were estimated in a structural path model.

\section{Measurement Model}

The overall chi-square statistic for the measurement model is significant $\left(c^{2}(641)\right.$ $=1175.08, p<.01$ ), as may have been expected given the sensitivity of this test statistic to sample size (Gerbing \& Anderson, 1992). The results of the first order CFA show that the measurement model fits the data reasonably well: $\mathrm{c}^{2} / d f=1.83$; RMSEA $=0.06 ;$ NNFI $=0.96$, CFI $=0.95$, Standardized RMR $=0.053(\mathrm{Hu} \&$ Bentler, 1999). The reliability of the construct was measured by the Joreskog r. All factors exceeded the minimal value of 0.70 (Fornell \& Larcker, 1981). All paths were significant at $p<.001$ ( $t$ values range from 6.11 to 36.39 ). Table 5 provides an overview of the measurement model.

\section{Structural Model}

To investigate the extent to which a customer's intention to repurchase can be predicted by both endogenous and exogenous constructs, a structural path model was estimated. Results indicate that the model had a reasonable fit with the data: $\mathrm{c}^{2}{ }_{(641)}=1216.16, p<.01, \mathrm{RMSEA}=0.06, \mathrm{NNFI}=0.94, \mathrm{CFI}=0.95$, Standardized $\mathrm{RMR}=0.065, \mathrm{c}^{2} / d f=1.84(1216.16 / 660)$. Three paths relating to global satisfaction were not found to be significant. Two were the attribute components of nice to use $(\gamma=0.04, \mathrm{t}=0.59)$ and comfort $(\gamma=0.07, \mathrm{t}=0.94)$ and one was the image component of additional benefits $(\gamma=-0.10, \mathrm{t}=1.50)$.

These paths were deleted to compute the final model which is presented in Figure 2. Despite the fact that $c^{2}$ is significant $\left(c^{2}{ }_{(663)}=1216.54, p<.01\right)$, the indices for the model revealed a reasonable fit: $\mathrm{RMSEA}=0.06, \mathrm{NNFI}=0.94, \mathrm{CFI}$ $=0.95$, Standardized RMR $=0.065, \mathrm{c}^{2} / d f=1.84(1216.54 / 663)$

${ }^{1}$ Note: the factor loading from service to global satisfaction is 0.34 with a $t$ value of 4.89 indicating a $p<.001$. 


\section{Table 5 Overview of the Measurement Model}

\begin{tabular}{|c|c|c|c|c|}
\hline $\begin{array}{l}\text { Latent } \\
\text { Constructs }\end{array}$ & Items & Loadings & $t$ & $\begin{array}{c}\text { Reliability } \\
\text { Joreskog } \\
\rho \\
\end{array}$ \\
\hline \multirow[t]{6}{*}{ Club services } & Advice of fitness instructors & 0.847 & 36.391 & 0.883 \\
\hline & Customized service & 0.799 & 28.711 & \\
\hline & $\begin{array}{l}\text { Qualification of fitness } \\
\text { instructors }\end{array}$ & 0.762 & 24.277 & \\
\hline & $\begin{array}{l}\text { Personal assessment and } \\
\text { follow up }\end{array}$ & 0.780 & 26.343 & \\
\hline & Staff availability & 0.760 & 24.098 & \\
\hline & Quality of programs & 0.499 & 9.515 & \\
\hline \multirow{5}{*}{$\begin{array}{l}\text { Customer } \\
\text { relations }\end{array}$} & Keeping promises & 0.782 & 24.295 & 0.825 \\
\hline & Access to information & 0.797 & 25.750 & \\
\hline & Responsiveness of staff & 0.713 & 18.749 & \\
\hline & Quality versus price & 0.659 & 15.511 & \\
\hline & Programs time table & 0.514 & 9.676 & \\
\hline \multirow[t]{4}{*}{ Security } & Modern equipment & 0.850 & 24.989 & 0.748 \\
\hline & Quality of equipment & 0.689 & 15.979 & \\
\hline & Safety & 0.654 & 14.339 & \\
\hline & Easy access to club & 0.381 & 6.110 & \\
\hline \multirow[t]{3}{*}{ Nice to use } & Kindness and smile & 0.884 & 30.668 & 0.833 \\
\hline & Kind welcome & 0.794 & 23.714 & \\
\hline & Pleasant atmosphere & 0.686 & 16.763 & \\
\hline \multirow[t]{2}{*}{ Comfort } & Cleanliness & 0.800 & 13.869 & 0.767 \\
\hline & Comfort & 0.778 & 13.576 & \\
\hline \multirow{9}{*}{$\begin{array}{l}\text { Promoted } \\
\text { image }\end{array}$} & Professionalism & 0.780 & 26.275 & 0.888 \\
\hline & Wellness & 0.728 & 21.086 & \\
\hline & Dynamism and vitality & 0.723 & 20.665 & \\
\hline & Fitness & 0.639 & 15.142 & \\
\hline & Recreation & 0.613 & 13.840 & \\
\hline & Service quality & 0.758 & 23.891 & \\
\hline & Sport & 0.699 & 18.854 & \\
\hline & Health & 0.576 & 12.211 & \\
\hline & Fun & 0.637 & 15.048 & \\
\hline \multirow{5}{*}{$\begin{array}{l}\text { Additional } \\
\text { benefits }\end{array}$} & Sun & 0.848 & 32.672 & 0.861 \\
\hline & Conviviality & 0.800 & 26.774 & \\
\hline & Holiday & 0.734 & 20.663 & \\
\hline & Place to meet people & 0.682 & 17.031 & \\
\hline & Peacefulness & 0.640 & 14.750 & \\
\hline
\end{tabular}




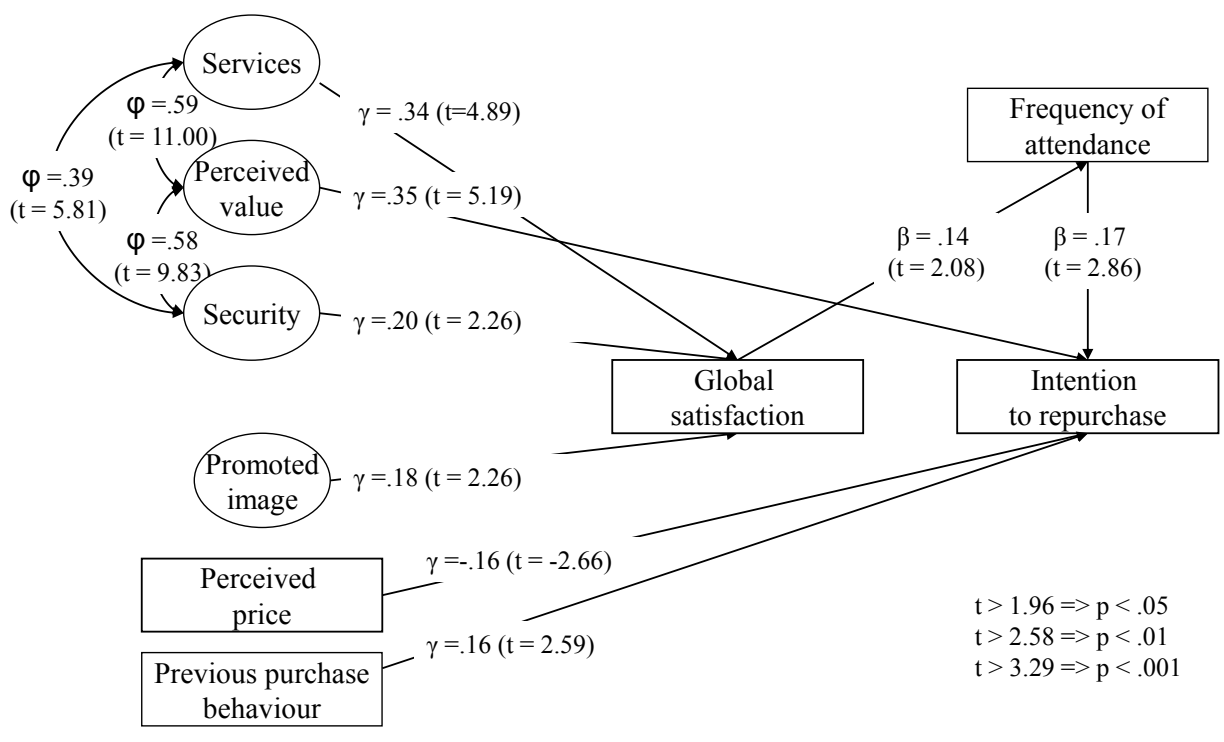

Figure 2 - Structural model.

As far as the relationships are concerned, significant path coefficients were found. This model shows that three constructs impact positively on customers' overall satisfaction. Two are dimensions related to the importance of Club Med's service attributes and are the services offered by the club $(\gamma=0.34, p<.05)$ and the security of the club $(\gamma=0.20, p<.05)$. The third construct is related to agreed brand attributes and is the promoted image of the club $(\gamma=0.18, p<.05)$.

Three constructs have a positive direct effect on intention to repurchase. These are the attributes that make up the customer relations dimension of the club $(\gamma=$ $0.35, p<.05)$, previous purchase behavior $(\gamma=0.16, p<.05)$ and their frequency of weekly attendance $(\beta=0.17, p<.05)$. Perceived price has a negative direct influence $(\gamma=-0.16, p<.05)$. Finally, the research showed that overall satisfaction has a slight positive impact on frequency of attendance $(\beta=0.14, p<.05)$.

As predicted, the importance of service attributes and agreed brand associations positively influence overall satisfaction. Furthermore, intention to repurchase is positively influenced by the importance of some service attributes, previous purchase behavior and frequency of attendance, and negatively by perceptions of the price of membership. Overall satisfaction had a positive impact on frequency of attendance. This provides support for $\mathrm{H} 2, \mathrm{H} 3, \mathrm{H} 4, \mathrm{H} 5, \mathrm{H} 6, \mathrm{H} 7$ and $\mathrm{H} 8$. However, satisfaction did not have a significant influence on intention to repurchase and therefore $\mathrm{H} 1$ is not supported.

\section{Discussion}

Contrary to the findings of Bernhart et al. (2000), Bitner et al. (1990), Cronin and Taylor (1994), Ganesh et al. (2000), Howat et al. (1999), Jones and Suh (2000), Olorunniwo et al. (2006), Patterson and Spreng (1997), and Söderlund (2006) this 
research did not find that overall satisfaction had a direct effect on intention to repurchase. Rather it adds to the body of literature that suggests that a consistent impact of satisfaction on intention to repurchase is yet to be confirmed (Hellier et al., 2003; Oliver, 1999; Zins, 2001). One possible explanation for this finding is that the impact that satisfaction has on intention to repurchase may be context specific in that there may be variables within each research setting that influence whether the relationship between satisfaction and intention to repurchase is direct or not. However, it is apparent that there is a relationship between the two variables which warrants continued research to inform understanding of customer behavior and subsequent management practice.

What the research did establish, however, is that in this case overall satisfaction had a positive impact on frequency of attendance, which in turn had a positive impact on intention to renew membership. Consequently frequency of attendance is a mediatory variable, and this seems a logical relationship. If customers are satisfied with the services offered by the club they are likely to attend more frequently than those who are not satisfied. Furthermore, if customers frequent a club more often they will perceive it to be of greater benefit to them than those who do not. This is likely to lead frequent users to have a greater intention to repurchase. In addition, it is possible to argue that frequent visiting is a form of behavioral loyalty and therefore seems likely to be directly related to other loyal behaviors, such as intention to repurchase. However, as the impact of frequency on intention to repurchase has not been subject to previous empirical research this relationship should be investigated further.

The customer relations factor created by the importance of certain service attributes (the responsiveness of staff, the keeping of promises, provision of information, the quality versus price ratio and timetabling) had a positive impact on intention to repurchase. This finding supports the work of Alexandris et al. (2001), Jones and Taylor (2007), and Nadiri et al. (2008) who found that important service attributes can have a direct positive impact on intention to repurchase.

In addition, previous purchase behavior, as indicated by length of membership, had a positive significant influence on intention to repurchase in that the longer a customer has been a member of the club, the more likely he/she was to say that they would renew their membership. This is not an unexpected finding; however, this finding does reinforce Oliver's (1999) proposal that loyal customers do not look to switch providers. This finding also supports McIlroy and Barnett's (2000) work with restaurant diners and the research done by Zins (2001) with customers of airlines which showed that customers who have a purchasing history with an organization remain with a brand and do not respond to competitor offers.

Finally, the research found a significant negative relationship between perceptions of price and intention to repurchase. This means that the more customers perceived the price to be expensive, the less likely they were to say they intended to renew their membership. Again, not a surprising finding that reflects the research of Keaveney (1995) and Jiang and Rosenbloom (2005).

The importance of other service attributes had no significant effect on intention to repurchase. However, they did impact on satisfaction with the service as established by the work of Alexandris et al. (2004), Costa et al. (2005), Howat et al. (1996), Lentell (2000), Papadimitriou and Karteroliotis (2000), and Theodorakis and Kambitsis (1998). However, as established by previous research (Busacca \& 
Padula, 2005; Erto \& Vanacore, 2002), not all service attributes were important to satisfaction. Reflecting the work of Alexandris et al. (2004), Busacca and Padula (2005), Costa et al. (2005), Ganesh et al. (2000), Lentell (2000), Olorunniwo et al. (2006), and Papadimitriou and Karteroliotis (2000), this study found that the importance of staff and the service they delivered had a positive impact on satisfaction. Security was also important as noted by Costa et al. (2005) in their work focusing on athletic camps. This suggests that attributes that impact on satisfaction are context and customer specific as it is difficult to identify trends across research settings. For example, the research carried out by Alexandris et al. (2004) found that the physical environment of a Greek health club had the strongest impact on satisfaction.

This research does not support the findings of Kandampully and Suhartanto (2000), and Zins (2001) who found that aspects of brand had a direct impact on intention to repurchase. In addition, the relationship between agreed brand associations and satisfaction was limited. Reflecting the work of Andreassen and Lindestad (1998), Beccarini and Ferrand (2006), Bolton and Drew (1991), Esch et al. (2006), Ferrand and Vecchiatini (2002), and Johnson and Fornell (1991), the dimension of promoted image had a positive impact on satisfaction, although additional benefits did not.

These findings have a number of possible explanations. First, the customers surveyed may not take advantage of the additional benefits offered by the club, or may consider them to be unimportant and thus, they do not impact on their satisfaction, or lead them to renew their membership. Second, the promoted image of Club Med Gym is made up of brand associations that reflect key reasons for joining the health and fitness club and therefore customers are likely to perceive these associations as being important when evaluating satisfaction. Should the club not live up to the image it markets and promotes, these associations are likely to lead to customer dissatisfaction.

In terms of the explanatory nature of the model, although it is satisfactory, the significant relationships between the variables are not particularly strong. This suggests that there are additional variables that have an impact on intention to repurchase which warrant further investigation in this context. One explanation may be customer diversity as they are likely to differ in terms of their expectations and motivations. Other variables such as proximity to work versus proximity to home, the availability of a range of membership types, and life stages of customers may make customers more or less likely to say they will repurchase. In addition, in support of the arguments of Ganesh et al. (2000) and McIlroy and Barnett (2000) satisfied customers may not repurchase as a consequence of offers from competitors. As stated earlier, this is a particular problem for the health and fitness industry where competition is regularly based on discounting.

\section{Managerial Implications}

Previous purchase behavior positively influences intention to repurchase and thus, it would appear logical for providers to attempt to develop long term relationships with customers and to do this by taking note of the chain that leads to repurchasing found by this research. Attributes relating to staff are important for customer satisfaction as is, to a lesser extent, the feeling of security customers have about 
the facility. These factors should lead to investment in qualified staff, staff training, equipment, and maintenance. This, alongside the promotion of an appropriate image, will lead customers to be satisfied with the service and visit more frequently. Increased frequency leads to intention to repurchase and repurchasing leads to future intention to repurchase.

More importantly, this research suggests that health and fitness providers need to create interpersonal relationships with their customers. By creating 'friendships' with their customers, they are able to encourage repurchasing behavior. Once again, staff are essential in maintaining loyalty as it is front-line staff who deal directly with customers. Managers should also focus on keeping promises, keeping customers informed, and good programming as these attributes are within direct management control.

This research showed that the importance of a number of service attributes has a direct impact on intention to repurchase, while the importance of others has an impact on customer satisfaction. It appears obvious to suggest that managers should focus on important attributes and deliver them as a level of quality that is appropriate for customers. However, what is perhaps of more interest to managers is that, once again, not all attributes had the same impact and that, although staff were, as usual, found to be important, the other attributes deemed important in this research did not closely reflect those deemed important in previous similar research. This suggests that, as outlined earlier, service attributes leading to customer satisfaction and intention to repurchase are organizational specific, which underlines the need for managers to identify the service attributes that are important to their particular customers and then to evaluate intention to repurchase against these specific service attributes. This will allow managers to focus on the attributes that are directly important to customer satisfaction and retention, rather than attempting to manage the performance of a range of service attributes, some of which may not be necessary.

The brand associations that are promoted via advertising to create an image of the club had an impact on customer satisfaction, while the additional benefits offered by the wider organization did not. This finding highlights the importance of brand image and suggests that managers need to create and maintain an image that reflects reasons for using health and fitness clubs as this is important in creating customer loyalty. This has an obvious disadvantage as well, in that if the image is not maintained, or does not live up to expectations, agreed brand attributes will impact negatively on satisfaction, which in turn will impact negatively on intention to repurchase.

Finally, the findings of the research also present a paradox for the providers of health and fitness clubs. The research suggests that frequency of attendance is a mediating variable on intention to repurchase, which is interesting as this concept does not appear to have been the object of previous research. However, herein lies the paradox. Encouraging customers to increase their frequency of attendance will increase the number of people in the club on a regular basis. An inevitable consequence of this is a greater demand on staff time, competition for personalized programs, competition for services, and decreases in the quality of equipment or a corresponding increase in the maintenance required. In short, the service and security dimensions of health and fitness clubs which were perceived to be important and that have a significant impact on satisfaction are likely to decline. 
It seems reasonable to suggest that a decline in the quality of the important service attributes that make up these dimensions will lead to a corresponding decline in the dimension of customer relations - a dimension considered important and that directly impacts on intention to repurchase. Thus, these research findings are problematic for providers who need to balance the need to increase frequency of attendance with the need to deliver high levels of service quality across the service attribute dimensions that are considered important by customers.

\section{References}

Aaker, D.A. (1991). Managing brand equity: Capitalizing on the value of a brand name. New York: The Free Press.

Aaker, D.A. (1996). Building strong brands. New York: The Free Press.

Agarwal, M.K., \& Rao, V.R. (1996). An empirical comparison of consumer-based measures of brand equity. Marketing Letters, 7, 237-247.

Andreassen, T.W., \& Lindestad, B. (1998). The effect of corporate image in the formation of customer loyalty. Journal of Service Research, 1, 82-92.

Alexandris, K., Dimitriadis, D., \& Kasiara, A. (2001). Behavioral consequences of perceived service quality: An exploratory study in the context of private fitness clubs in Greece. European Sport Management Quarterly, 1, 251-280.

Alexandris, K., Zahariadis, P., Tsorbatzoudis, C., \& Grouios, G. (2004). An empirical investigation of the relationships among service quality, customer satisfaction and psychological commitment in a health club context. European Sport Management Quarterly, 1, 36-52.

Bagozzi, R.P., \& Yi, Y. (1988). On the evaluation of structural equation models. Journal of the Academy of Marketing Science, 16, 74-94.

Beccarini, C., \& Ferrand, A. (2006). Factors affecting soccer club season ticket holders' satisfaction: the influence of club image and fans motives. European Sport Management Quarterly, 6, 12-26.

Belén del Río, A., Vázquez, R., \& Iglesias, V. (2001). The effects of brand associations on consumer response. Journal of Consumer Marketing, 18, 410-426.

Bernhart, K., Donthu, N., \& Kennet, P. (2000). A longitudinal analysis of satisfaction and profitability. Journal of Business Research, 47, 161-171.

Bitner, M.J., Booms, B.H., \& Tétreault, M. (1990). The service encounter: diagnosing favorable and unfavorable incidents. Journal of Marketing, 54, 71-84.

Bolton, R.N., \& Drew, J.H. (1991). A multistage model of customers' assessments of service quality and value. The Journal of Consumer Research, 17, 375-384.

Bou-Llusar, J.C., Camison-Zornoza, C., \& Escrig-Tena, A.B. (2001). Measuring the relationship between firm perceived service quality and customer satisfaction and its influence on purchase intentions. Total Quality Management, 12, 719-734.

Busacca, B., \& Padula, G. (2005). Understanding the relationship between attribute performance and overall satisfaction. Marketing Intelligence \& Planning, 23, 543-561.

Chen, A.C. (2001). Using free association to examine the relationship between the characteristics of brand associations and brand equity. Journal of Product and Brand Management, 10, 439-451.

Costa, G., Tsitskari, E., Tzetzis, G., \& Goudas, M. (2005). The factors for evaluating service quality in athletic camps: A case study. European Sport Management Quarterly, $1,22-35$.

Crompton, J.L., MacKay, K.J., \& Fesenmaier, D.R. (1991). Identifying dimensions of service quality dimensions in public recreation. Journal of Park and Recreation Administration, 9, 15-27. 
Cronin, J., \& Taylor, S. (1994). SERVPERF versus SERVQUAL: Reconciling performancebased perceptions-minus-expectations measurement of service quality. Journal of Marketing, 58, 125-131.

Dimitriades, Z. (2006). Customer satisfaction, loyalty and commitment in service organizations. Management Research News, 29, 782-800.

Divett, M., Crittenden, N., \& Henderson, R. (2003). Actively influencing consumer loyalty. Journal of Consumer Marketing, 20, 109-126.

Erto, P., \& Vanacore, A. (2002). A probabilistic approach to measure hotel service quality. Total Quality Management, 13, 165-174.

Esch, F., Langer, T., Schmitt, B.H., \& Geus, P. (2006). Are brands forever? How brand knowledge and relationships affect current and future purchases. Journal of Product and Brand Management, 15, 98-105.

Ferrand, A., \& Nardi, M. (1995). Fitness Marketing. Milan, IT: Alea Edizioni.

Ferrand, A., \& Vecchiatini, D. (2002). The effect of service performance and ski resort image on skiers' satisfaction. European Journal of Sport Science, 4, 24-38.

Fornell, C., \& Larcker, D.F. (1981). Evaluating structural equation models with unobservable variables and measurement error. JMR, Journal of Marketing Research, 18, 39-50.

Fornell, C., \& Wernerfelt, B. (1987). Defensive marketing strategy by customer complaint management: A theoretical analysis. JMR, Journal of Marketing Research, 24, 337-346.

Fredericks, J.O., \& Salter, J.M. (1995). Beyond customer satisfaction. Management Review, $84,29-32$.

Ganesh, J., Arnold, M., \& Reynolds, K. (2000). Understanding the customer base of service providers: An examination of the differences between switchers and stayers. Journal of Marketing, 64, 65-87.

Gerbing, D.W., \& Anderson, J.C. (1992). Monte Carlo evaluations of goodness of fit indices for structural equations models. Sociological Methods \& Research, 21, 132-160.

Gladden, J.M., Milne, G.R., \& Sutton, W.A. (1998). A conceptual framework for assessing brand equity in Division I college athletics. Journal of Sport Management, 12, 1-19.

Gladden, J.M., \& Funk, D.C. (2002). Developing an understanding of brand associations in team sport: Empirical evidence from consumers of professional sport. Journal of Sport Management, 16, 54-81.

Grace, D., \& O'Cass, A. (2005). Examining the effects of service brand communications on brand evaluation. Journal of Product and Brand Management, 14, 106-116.

Hellier, P.K., Geursen, G.M., Carr, R., \& Rickard, J.A. (2003). Customer repurchase intention: A general structural equation model. European Journal of Marketing, 37, 1762-1800.

Hill, B., \& Green, B.C. (2000). Repeat attendance as a function of involvement, loyalty and the sportscape across three football contexts. Sport Management Review, 3, 145-162.

Howat, G., Crilley, G., Absher, J., \& Milne, I. (1996). Measuring customer service quality in sports and leisure centers. Managing Leisure: An International Journal, 1, 77-90.

Howat, G., Murray, D., \& Crilley, G. (1999). The relationships between service problems and perceptions of service quality, satisfaction, and behavioral intentions of Australian public sport and leisure centre customers. Journal of Park and Recreation Administration, 17, 42-64.

Hu, L., \& Bentler, P.M. (1999). Cutoff criteria for t indexes in covariance structure analysis: Conventional criteria versus new alternatives. Structural Equation Modeling, 6, 1-55.

International Health, Racquet and Sportsclub Association. (2006). State of the health club industry. Global Market Report. Boston, MA: IHRSA.

Ipsos. (2005). French and body fitness: Market report. Retrieved May 17, 2007, from www. ipsos.fr/Canallpsos/articles/1521.asp

Jiang, P., \& Rosenbloom, B. (2005). Customer intention to return online: price perception, attribute-level performance, and satisfaction unfolding over time. European Journal of Marketing, 1, 150-174. 
Johnson, M.D., \& Fornell, C. (1991). A framework for comparing customer satisfaction across individuals and product categories. Journal of Economic Psychology, 12, 267-286.

Jones, M.A., \& Suh, J. (2000). Transaction specific satisfaction and overall satisfaction: an empirical analysis. Journal of Services Marketing, 14, 147-159.

Jones, T., \& Taylor, S.F. (2007). The conceptual domain of service loyalty: how many dimensions? Journal of Services Marketing, 21, 36-51.

Jöreskog, K., \& Sörbom, D. (2003). LISREL 8.54. Chicago: Scientific Software International.

Kandampully, J., \& Suhartanto, D. (2000). Customer loyalty in the hotel industry: the role of customer satisfaction and image. International Journal of Contemporary Hospitality Management, 12, 346-351.

Keaveney, S.M. (1995). Customer behavior in services industries: an exploratory study. Journal of Marketing, 59, 71-82.

Keller, K.L. (1993). Conceptualizing, measuring, and managing customer-based brand equity. Journal of Marketing, 57, 1-22.

Kim, C., \& Kim, S.Y. (1998). Segmentation of sport center members in Seoul based on attitudes towards service quality. Journal of Sport Management, 12, 273-287.

Lassar, W., Mittal, B., \& Sharma, A. (1995). Measuring customer-based brand equity. Journal of Consumer Marketing, 12, 11-19.

Lentell, R. (2000). Untangling the tangibles: 'physical evidence' and customer satisfaction. Managing Leisure: An International Journal, 1, 1-16.

Lincoln, Y.S., \& Guba, E.G. (1985). Naturalistic inquiry. London: Sage.

Lovelock, C., \& Wright, L. (1999). Principles of service marketing and management. Englewood Cliffs, NJ: Prentice Hall.

McIlroy, A., \& Barnett, S. (2000). Building customer relationships: Do loyalty cards work? Managing Service Quality, 10, 347-355.

Murray, D., \& Howat, G. (2002). The relationships among service quality, value, satisfaction, and future intention of customers at an Australian sports and leisure centre. Sport Management Review, 5, 25-43.

Nadiri, H., Hussain, K., Ekiz, E., \& Erdoğan, S. (2008). An investigation on the factors influencing passengers' loyalty in the North Cyprus national airline. The TQM Journal, 20, 265-280.

Nunnally, J.C., \& Bernstein, I.H. (1994). Psychometric theory (3rd ed.). New York: McGrawHill.

Oliver, R. (1999). Whence customer loyalty? Journal of Marketing, 63, 33-44.

Olorunniwo, F., Hsu, M.K., \& Udo, G.J. (2006). Service quality, customer satisfaction, and behavioral intentions in the service factory. Journal of Services Marketing, 20, 59-72.

Papadimitriou, D., \& Karteroliotis, K. (2000). The service quality expectations of private sport and fitness centers: A re-examination of the factor structure. Sport Marketing Quarterly, 9, 157-165.

Pappu, R., \& Quester, P. (2006). Does customer satisfaction lead to improved brand equity? An empirical examination of two categories of retail brands. Journal of Product and Brand Management, 15, 4-14.

Parasuraman, A., Zeithaml, V., \& Berry, L. (1985). A conceptual model of service quality and its implications for future research. Journal of Marketing, 49, 41-50.

Parasuraman, A., Zeithaml, V., \& Berry, L. (1988). SERVQUAL: A multiple item scale for measuring consumers perceptions of service quality. Journal of Retailing, 64, 13-40.

Parasuraman, A., Zeithaml, V., \& Berry, L. (1994a). Alternative scales for measuring service quality: A comparative assessment based on psychometric and diagnostic criteria. Journal of Retailing, 70, 201-230.

Parasuraman, A., Zeithaml, V., \& Berry, L. (1994b). Reassessment of expectations as a comparison study in measuring service quality: implications for further research. Journal of Marketing, 58, 111-124. 
Park, S., \& Kim, Y. (2000). Conceptualizing and measuring the attitudinal loyalty construct in recreational sport contexts. Journal of Sport Management, 14, 197-207.

Patterson, P.G., \& Spreng, R.A. (1997). Modeling the relationship between perceived value, satisfaction and repurchase intentions in a business-to-business, services context: An empirical investigation. International Journal of Services Management, 8, 414-434.

Patton, M.Q. (2002). Qualitative research and education methods. Thousand Oaks, CA: Sage.

Reichheld, F.F. (2003). The one number you need to grow. Harvard Business Review, 81, $46-54$.

Ross, S.D. (2006). A conceptual framework for understanding spectator-based brand equity. Journal of Sport Management, 20, 22-38.

Ross, S.D., James, J.D., \& Vargas, P. (2006). Development of a scale to measure team brand associations in professional sport. Journal of Sport Management, 20, 260-279.

Selin, S., Howard, D.R., Udd, E., \& Cable, T. (1987). An analysis of consumer loyalty to municipal recreation programs. Leisure Sciences, 10, 217-223.

Söderlund, M. (2006). Measuring customer loyalty with multi item scales: A case for caution. International Journal of Service Industry Management, 17, 76-98.

Srivastava, J. (1999). Price-matching refund policies as a signal of store price image. MSI Report, 1-37.

Theodorakis, N., \& Kambitsis, C. (1998). The effect of service quality on sport consumer's behavior intentions. $5^{\text {th }}$ European Association for Sport Management: Conference proceedings, 2.71-2.76.

Zeithaml, V., Berry, L.L., \& Parasuraman, A. (1996). The behavioral consequences of service quality. Journal of Marketing, 60, 31-46.

Zins, A.H. (2001). Relative attitudes and commitment in customer loyalty models. Journal of Service Industry Management, 12, 269-294. 